\title{
Punishment of Persons Convicted of Economic (Business) Crimes and Malfeasance in Office, in the Assessment of the Public and Professionals
}

\author{
VYACHESLAV I. SELIVERSTOV \\ Lomonosov Moscow State University, Moscow, Russian Federation \\ Moscow State Linguistic University, Moscow, Russian Federation \\ ORCID: https://orcid.org/0000-0002-9554-5438, e-mail: vis_home@list.ru
}

\begin{abstract}
Introduction: the article considers ultra-liberal, ultra-radical and realistic views on the punishment of persons convicted of economic (business) crimes and malfeasance in office. The article analyzes public and professional opinion on this problem using the results of specific sociological studies conducted in 2018-2019 by Tkachevsky Research and Education Center "Problems of Penal Law" under Lomonosov Moscow State University. Research materials and methods: the research is based on the application of the specific sociological research method. The materials for our research include the results of the study of public and professional opinion on the punishment of those convicted of economic crimes and malfeasance in office, and on the places and conditions of their imprisonment. Empirical research includes surveys of three types of respondents: citizens of the Russian Federation; persons convicted of economic crimes and malfeasance in office who are serving sentences in correctional institutions; correctional officers. We also investigate proposals on sending the convicts under consideration to correctional institutions located in remote regions of Russia, and the prospects for the construction and opening of so-called private prisons for them. We analyze the practice of keeping persons convicted of economic crimes and malfeasance in office together with other categories of convicts. Results: we conclude that the public and professionals do not tend to hold extreme positions (ultra-liberal or ultra-radical) in the punishment of persons convicted of economic crimes and malfeasance in office. The public and professionals assess quite realistically the criminal policy of the state and judicial practice at the present stage of the state's development and allow, within certain limits, the application of punishment in the form of imprisonment to economic and official criminals. We emphasize that both categories of respondents (citizens and convicts) are more inclined to use imprisonment in relation to persons who have committed malfeasance in office than to those who committed economic crimes. We argue that public opinion is dissatisfied with the fact that persons convicted of malfeasance in office and economic crimes are kept together with other categories of convicts. There is no such dissatisfaction in the professional opinion: the majority of interviewed correctional officers do not support the idea of sending those convicted of economic crimes and malfeasance in office to separate correctional institutions. We put forward a proposal concerning the implementation of the idea that persons convicted of economic crimes and malfeasance in office should be held in separate correctional institutions in the course of modernization provided for by the Concept for development of the penal system of the Russian Federation until 2030, which consists in opening joint correctional institutions.

Keywords: convicted person; economic crimes; malfeasance in office; public opinion; professional opinion; punishment; imprisonment; correctional institutions; private prisons.
\end{abstract}

12.00.08 - Criminal law and criminology; penal law.

For citation: Seliverstov V.I. Punishment of persons convicted of economic (business) crimes and malfeasance in office, in the assessment of the public and professionals. Penitentiary Science, 2021, vol. 15, no. 3 (55), pp. 613-620. DOI 10.46741/2686-9764-2021-15-3-613-620. 


\section{Introduction}

Issues related to countering economic and official crime in Russia are of great interest not only to scientists and practitioners working professionally in this field, but also to ordinary citizens. Traditionally, this interest is fueled by the mass media, which feed us with news about seized funds measured in tons, or "golden toilets" in the homes of corrupt officials and robbers of various stripes. As a result, according to the survey conducted by Tkachevsky Research and Education Center "Problems of Penal Law" under Lomonosov Moscow State University (REC "Problems of Penal Law"), the extent of crime in economic (entrepreneurial) activity worries $90 \%$ of the surveyed citizens, in the field of official crimes $-95.6 \%$. The respondents consider the following crimes as most dangerous in our country: malfeasance in office $(51.9 \%$ - 1st place), terrorism $(47.8 \%$ - 2nd place), murder and other crimes against the person $(41.1 \%$ - 3rd place), economic (in the field of entrepreneurship) crimes $(38.5 \%-4$ th place), drug crime $(37.7 \%$ - 5th place), pedophilia $(29.9 \%-6$ th place). One in three respondents, along with the noted types of criminal activity, indicated that all types of crime are equally dangerous. Thus, at present, official and economic crime in the field of entrepreneurship (hereinafter referred to as simply economic crime, economic crimes and those convicted of economic crimes) are among the four most dangerous types of crime.

State authorities are also seriously concerned about official crime, as it directly affects their standing among the population. And this reason is not the only one. For example, the Federal Penitentiary Service is concerned about the ever increasing number of inmates in correctional institutions for former employees of law enforcement agencies [7]. This concern is due to the fact that it is necessary to open separate correctional colonies for such individuals.

So, what can be offered for the punishment of these categories of convicts? Can incarceration be applied to them and what should it be, taking into account the specifics of the sociodemographic and criminological characteristics of persons committing economic crimes and malfeasance in office?

Research materials and methods. The research is based on the application of the specific sociological method. The research materials are the results of the study of public and professional opinion on the punishment of per- sons convicted of economic and official crimes, as well as on the places and conditions of their imprisonment. Empirical research consists of surveys of three types of respondents: citizens of the Russian Federation; convicts serving sentences in correctional institutions for committing economic and official crimes; employees of correctional institutions. The volume of surveys and the characteristics of respondents are as follows.

Citizens of the Russian Federation. Five hundred and one respondents took part in the Internet survey: $41 \%$ were men and $59 \%$ - women. Age distribution of respondents was as follows: from 18 to 25 years old - 53\%; from 26 to 45 years old $-33 \%$; from 46 to 60 years old $-9 \%$; over 60 years old $-5 \%$. Sixty percent had higher professional education, $27 \%$ - incomplete higher education, $12 \%$ - full secondary general and vocational education (college), and $1 \%$ of respondents had other types of education.

Convicted persons serving a prison sentence. The survey involved 213 persons serving prison sentences for committing economic and official crimes. The survey was conducted in correctional institutions in the Far Eastern, Siberian, Ural, Volga and Central federal districts. The sample included male (93\%) and female (7\%) convicts. Age distribution of convicts was as follows: from 18 to 25 years old - 11\%; from 26 to 45 years old - 52\%; from 46 to 60 years old $-37 \%$. By education: $3 \%$ have incomplete secondary education, $18 \%$ have full secondary education, $61 \%$ have secondary vocational and incomplete higher education, and $18 \%$ of respondents have higher education.

Correctional officers. The survey covered 234 employees at correctional colonies in the Far Eastern, Siberian, Ural, Volga and Central federal districts. According to the length of service in the penal system, their distribution was as follows: up to 5 years - 19\%, from 5 to 10 years $-41 \%$, from 10 to 20 years $-35 \%$, from 20 and more $-5 \%$. The survey participants represented the following departments: security departments (27\%), guard departments (15\%), operational departments (6\%), educational service units (25\%), medical services (3\%), logistics departments (4\%), personnel departments (4\%), heads of departments and services of correctional institutions (3\%), employees of other areas of activity (13\%); $77 \%$ of respondents had higher and incomplete higher education, $14 \%$ had secondary vocational education, and $9 \%$ had secondary education. 
In addition, expert assessments of domestic and foreign scientists, as well as media materials were used.

\section{Discussion}

The professional community and public opinion have different views on the punishment of persons who have committed economic and official crimes: from extremely mild to extremely severe. We can talk about three different positions.

The first position is ultra-liberal. It manifests itself in relation to economic crimes in views that exclude the imposition of a criminal penalty in the form of imprisonment. This position is held by a number of representatives of political and human rights organizations, business elites, who believe that fines and other economic sanctions should be applied in cases of economic crimes. This position is reflected in a number of Addresses of the President of the Russian Federation to the Federal Assembly of the Russian Federation and in the Concept for modernization of criminal legislation in the economic sphere prepared at the end of 2009 by the autonomous non-profit organization "Center for Legal and Economic Research" in cooperation and with the support of a number of scientific and educational organizations on the basis of the instruction of the President of the Russian Federation. It was also supported by foreign experts from Slovenia and Kazakhstan, who were invited to the 11th Russian Congress on Criminal Law (Moscow, Lomonosov Moscow State University, May 31 - June 1, 2018) to evaluate the theoretical model for serving imprisonment by persons convicted of economic and (or) official crimes developed at REC "Problems of Penal Law". As Professor G. Me ko (Republic of Slovenia) pointed out, compensation for damage and confiscation of illegally acquired property could potentially be the best judicial decision, as opposed to punishment in the form of imprisonment [10, p. 112]. Professor A.B. Skakov (Republic of Kazakhstan) proposed his own solution to this problem: to sentence this category of persons to the most common type of punishment in the world - a fine in favor of the state, a threefold compensation to the injured party, and confiscation of property obtained by criminal means [16, p. 121].

The second position is ultra-radical. It is practiced, as a rule, by politicians, but there are also representatives of legal science among its advocates.

Thus, in January 2019, the first deputy chairman of the State Duma Committee on Defense of the Russian Federation proposed to introduce not only death penalty for corrupt officials of all stripes, but also the practice of burying their bodies at separate cemeteries for the edification of other citizens [4]. In August 2021, the head of Roscosmos said that corruption in the national military-industrial complex should be punished by execution by firing squad, and not by imprisonment [15].

In legal science, proposals have been made to introduce the practice of extrajudicial executions via medical manipulation (Tyumen) or by creating and operating a kind of "death squads" (Krasnodar, Saint Petersburg), etc. Currently, such views are virtually not found anywhere.

We should note that we cannot support the proposals of representatives of the ultra-radical position. Extrajudicial executions and burials are a way to a dead end, which our country has already faced during the years of Stalin's repressions in the past century. Negative implications of this practice still linger. The revival of capital punishment for corruption crimes in a legal manner does not correspond to Russia's international obligations. In addition, this measure of punishment does not fully meet the severity of the economic and official crimes committed. The proposal to bury the executed corrupt officials in separate cemeteries does not lend itself to scientific assessment.

The third - realistic - position is the application of criminal punishment in the form of imprisonment to those convicted of economic crimes and malfeasance of office in accordance with current legislation. Its supporters, while assessing the views of the representatives of the first position, believe that the ultraliberal version of modernization of criminal law proposed by the science in relation to economic crime is mainly aimed at the complete exclusion of repression for the crimes of the group under consideration, which will have the most negative impact on the state of crime in modern society. The implementation of the proposals contained in the Concept for modernization of criminal legislation in the economic sphere will lead to an increase in social inequality of various population strata, which can cause a social explosion [2, pp. 29-32; 3, p. 16; 8, p. 448; 11, p. 357].

Indeed, the events of recent years with specific examples of economic crimes (for example, falsification of alcohol or other products, which led to mass poisoning) and malfeasance of office (for example, taking bribes and largescale abuse and embezzlement of budget 
funds) do not allow us to lean toward such a liberal conclusion as the exclusion of the application of criminal punishment in the form of imprisonment to economic and official criminals. This is also evidenced by the results of the public opinion survey.

Thus, according to the survey of citizens, $71 \%$ do not exclude the possibility of sentencing to imprisonment for economic crimes: $20 \%$ answered categorically that economic criminals should be sentenced to imprisonment, and 51\% think that imprisonment is possible when deciding on its imposition strictly individually, taking into account specific circumstances. More indicative results were obtained when the similar question was asked in relation to persons who committed malfeasance of office; namely, $76 \%$ of respondents do not exclude a custodial sentence: $35 \%$ answered categorically that imprisonment should necessarily be assigned to official criminals (this percentage is almost twice as high as when respondents answered a similar question in relation to economic criminals), and $41 \%$ allow deprivation of liberty when deciding on its appointment strictly individually, taking into account specific circumstances.

It is also noteworthy that in a parallel survey of convicts serving imprisonment for economic and official crimes, almost two-thirds of respondents (64\%) do not exclude the possibility of a custodial sentence for economic crimes: $15 \%$ answered categorically that economic criminals should be sentenced to imprisonment, and $49 \%$ allow deprivation of liberty when deciding on its appointment strictly individually, taking into account specific circumstances. Only $16 \%$ answered that there is no need for imprisonment, and it is possible to impose other types of punishment (a fine, deprivation of the right to hold certain positions and engage in certain activities, etc.). Similar results were obtained when this question was asked in relation to persons who committed malfeasance of office. Thus, more than half $(57 \%)$ of respondents do not exclude the imposition of custodial penalty: $27 \%$ answered categorically that official criminals should be sentenced to imprisonment (this percentage is almost twice as high as when a similar question is asked in relation to economic criminals), and $30 \%$ allow deprivation of liberty when deciding on its appointment strictly individually, taking into account specific circumstances. Only $16 \%$ of respondents believe that there is answered that there is no need for imprisonment in relation to persons who committed malfeasance of office, and it is possible to impose other types of punishment on them (a fine, deprivation of the right to hold certain positions and engage in certain activities, etc.).

The position on the possibility and necessity of imposing a custodial penalty on persons who have committed economic and official crimes was supported by foreign experts from the republics of Belarus and Kazakhstan (Professor V.B. Shabanov [18, pp. 124-143] and Professor T.K. Akimzhanov [1, pp.144-153]), who were invited to evaluate the theoretical model for serving imprisonment by persons convicted of economic and (or) official crimes developed at REC "Problems of Penal Law".

The logical continuation of the position under consideration is the placement of those convicted of economic and official crimes in currently functioning correctional institutions. However, there are certain nuances in this position.

The question immediately arises regarding where and to which correctional institutions these persons should be placed to serve their sentences. These may be correctional colonies at the place of permanent residence, or there may be colonies in remote areas. Such a proposal was made in the science of penal law in relation to determining the place of serving imprisonment for major economic criminals and bribe takers operating as part of organized criminal groups and communities [17].

In our opinion, this proposal is not fully developed and justified. On the one hand, it is necessary to assess whether the categories of convicts under consideration are actually this dangerous. It is possible that terrorism and other types of crimes are more dangerous in their implications, and those convicted of these crimes should serve their sentences in correctional colonies stationed in the Far North, Siberia and other remote areas.

On the other hand, when working on the implementation of this proposal in relation to economic and official criminals, it will be necessary to predict the reaction of international human rights organizations, especially the European Court of Human Rights. There are several decisions of the highest judicial body of Europe in relation to Russia, in which the court found a violation of Article 8 of the European Convention for the Protection of Human Rights and Fundamental Freedoms (the right to respect for family and private life) in connection with the transfer of convicted persons to serve their sentences in correctional colonies located in areas remote from the family's place of residence (decision in 
case no. 35090/09 of March 7, 2017 "Polyakova and others v. the Russian Federation"; decision in case no. 39747/10 of July 3, 2018 "Voynov v. Russia"). Is it possible that the Court can adopt similar decisions in this case as well?

In addition, it is necessary to take into account current trends in the penal enforcement policy of Russia, which indicate that the Russian Federation does not question the above-mentioned decisions of the European Court of Human Rights (although there currently exist certain constitutional grounds for non-compliance with such decisions) and has begun to implement them consistently, introducing legal and organizational guarantees for the realization of the legitimate interest of a convicted person to serve a prison sentence near the place of residence of his/her family. The fact that this trend will take place in the future is evidenced by the Concept for development of the penal system of the Russian Federation until 2030 (hereinafter - Concept-2030), which states one of the important tasks of "creating conditions for ensuring the implementation of the legally binding principle of serving sentences in correctional institutions within the territory of the constituent entity of the Russian Federation in which they lived or were convicted or in which their family lives" [13].

Representatives of business structures and individual human rights defenders have their own position on the places where economic criminals serve their custodial sentences. Based on the experience of a number of foreign countries (France, the U.S., the UK, etc.), they propose to open private prisons for businesspeople $[5 ; 12]$. The need to study the issue of public-private partnership with the subsequent establishment of private prisons, following the example of the UK, was pointed out in the expert opinion by a foreign expert, Professor G. Me ko (Republic of Slovenia). However, he warned that the effectiveness of private prisons created with the consent of the state is ambiguous [10, p. 110].

Publications on the activities of foreign penitentiary systems [14, pp. 215-266] show that private prisons require significantly higher material costs on the part of the state, which is not quite possible for the Russian Federation in the modern conditions of economic sanctions. For business, the idea of establishing private prisons in Russia at present may be interesting not so much in terms of obtaining material benefits, but in the aspect that socially responsible businesses provide assistance in implementing an important state task to combat crime. So far, there is no such interest on the part of either the state or business structures in the construction and operation of private prisons. Therefore, the problem of private prisons needs a more thorough economic and social examination, among other things in the aspect of finding the optimal balance of the interests of the state and business.

But if there is no possibility of opening separate private prisons for economic criminals, then it is quite possible to implement the idea expressed by Presidential Commissioner for Entrepreneurs' Rights Boris Titov at the Far Eastern Economic Forum (September 2018). He announced that an agreement had been reached with the leadership of the Federal Penitentiary Service of Russia on the placement of these persons into separate blocks of pre-trial detention centers as an experiment [9]. However, these steps may turn out to be half-hearted, since in the end, suspects and accused of committing economic crimes, as a rule, become convicted and are sent to ordinary places of deprivation of liberty. And the Russian Ombudsman for the Protection of Entrepreneurs' Rights understands this danger, which is evident from his following statement: "We have applied to the Federal Penitentiary Service with this proposal, because it is a huge problem when those convicted of economic crimes are held together with jailbirds. And it is always harder for businesspeople to be in prison, especially in a colony, not even in a pre-trial detention center" [6].

The Russian Ombudsman for the Protection of Entrepreneurs' Rights raised a very complex, but topical issue about the fact that persons convicted of economic crimes are kept together with those convicted of other types of crimes (against the person, drug trafficking, etc.). This problem is also relevant for persons serving sentences for malfeasance in office, since they, as a rule, have the same socio-demographic and criminological characteristics as those convicted of economic crimes. Without questioning the legality and validity of the sentence against these persons, we will ask ourselves the question: should they serve their sentences together with murderers, terrorists, drug dealers?

According to the results of the survey, $44 \%$ of respondents consider it necessary for those convicted of economic crimes to serve their imprisonment in separate correctional colonies, and $32 \%$ of respondents hold this opinion with regard to those convicted of official crimes. 
Among the staff of correctional institutions, $16 \%$ of respondents unequivocally supported the proposal on separate correctional institutions for those convicted of economic crimes (for official crimes - 15\%); another $7 \%$ supported this idea, provided that persons convicted of economic crimes pay for their detention in separate correctional colonies (for malfeasance in office $-6 \%$ ). The majority of correctional officers reject this idea: $39 \%$ do not support it for economic criminals (for malfeasance in office $-42 \%$ ), $21 \%$ consider it impossible to implement this idea due to high material costs (for malfeasance in office - 16\%). One in six (17\%) respondents found it difficult to answer this question (in relation to those convicted of official crimes - 21\%).

Despite the negative opinion of the staff of correctional institutions, we believe there are grounds for separating persons convicted of economic and official crimes from other categories of inmates. It is not only their socio-demographic and criminological characteristics, but also the situation that often develops in correctional institutions around these categories. It seems that the Russian Ombudsman for the Protection of Entrepreneurs' Rights had both the information and the grounds to declare that "it is always harder for businesspeople to be in prison, especially in a colony, not even in a pretrial detention center". The mass media have reported many times about the facts of harassment of this category of convicts, extortion of property and money from them. These negative phenomena were reflected, though not to the fullest extent, in the survey of those convicted of economic and official crimes.

Thus, answering the question about whether there were any facts of harassment (insults, use of physical force, bullying) of those convicted of economic crimes, the respondents expressed the following opinion. The majority of respondents (64\%) replied that they had not encountered such facts. One in four respondents (26\%) found it difficult to answer this question. At the same time, almost every tenth (9\%) respondent replied that such facts had taken place. One convict replied that he was afraid to answer this question, from which it can be concluded that these facts exist, but many hide them.

The results of the answer to the question of whether there were facts of extortion of money, property, business from those convicted of economic crimes by other convicts were as follows. The majority of respondents (60\%) deny such facts; $24 \%$ of respondents found it difficult to answer this question. At the same time, almost one in ten (9\%) replied that there had been facts of extortion. Some respondents (7\%) noted that there had been such facts, but they had been requests from convicts rather than extortion.

Similar results were obtained when answering questions about those who committed malfeasance of office.

Thus, when asked whether the respondents had met with the facts when other convicts harassed (insulted, used physical force, bullied) those convicted of official crimes, more than half $(59 \%)$ replied that they had not met with such facts while serving their sentence. Almost every third person (30\%) found it difficult to answer this question. At the same time, $11 \%$ of convicts met with such facts.

When asked whether there were facts when other convicts extorted money, property, business from those convicted of official crimes, the majority of respondents (62\%) replied that there were no such facts. Every fourth (26\%) found it difficult to answer this question, but almost every twelfth $(8 \%)$ noted that such facts had been requests from convicts rather than extortion. However, $4 \%$ of respondents confirm the facts of extortion.

At the same time, we cannot ignore the arguments of opponents of sending those convicted of economic and official crimes to separate correctional institutions.

First of all, it is an economic factor: sending convicts to separate correctional colonies will increase budget expenditures, in particular for the transportation of convicts, since there will be few such correctional colonies. Employees of correctional colonies pointed to material expenses as an obstacle to the implementation of the idea of separating economic (21\%) and official (16\%) criminals.

The foreign policy factor in the form of a possible violation of Article 8 of the European Convention for the Protection of Human Rights and Fundamental Freedoms is also important, since there is a risk of increasing the proportion of convicts serving imprisonment far from the place of permanent residence of their families.

Purely pragmatic considerations should also be taken into account. It is no secret that the administration often uses the experience and (or) connections of those convicted of economic and official crimes for the purposes of establishing production in the colonies. Would it be justified to deprive them of this kind of additional mechanism for intensifying produc- 
tion activities and providing convicts with work, if those convicted of economic and official crimes would be held in separate correctional colonies? In our opinion, before such a decision is made, additional scientifically substantiated measures should be implemented to improve the situation with the involvement of convicts in paid work.

Results

As it is clear from the above, public and professional opinion is not inclined to share extreme positions (ultra-liberal or ultra-radical) in matters of punishing economic and official criminals. It quite realistically assesses the criminal policy and judicial practice at the present stage of the state's development and allows, within certain limits, the punishment in the form of imprisonment to be applied to economic and official criminals. We should particularly note that both categories of persons interviewed in the framework of this study tend to approve the imprisonment of persons who have committed malfeasance in office rather than economic criminals.

At the same time, we see that in the public opinion, there is dissatisfaction with the fact that economic and official criminals serve their custodial sentences together with other categories of convicts. There is no such dissatisfaction in the professional opinion: the majority of the interviewed correctional officers do not support the idea of sending such convicts to separate correctional institutions.

At the same time, in modern conditions characterized by contradictory development of the market economy and inherent corruption of the state apparatus, the task of further differentiation of those sentenced to imprisonment remains urgent. This task is based on the provisions of the Concept-2030, which defined measures to ensure security in correctional institutions and create conditions for separate detention of various categories of convicts. It seems that the implementation of these conceptual provisions can be carried out in different ways, including the allocation of persons convicted of economic and official crimes to a separate group within the framework of modernization of the penal system planned in the Concept-2030. One of the specific directions of such modernization in the concept document provides for the development and implementation of a project to create a unified type of institution by 2024 . It means the concentration of various types of correctional institutions and pre-trial detention facilities in a single center on a regional or even interregional basis.

The opening of joint correctional (multifunctional) institutions is a rather large and ambitious project. This work can continue for more than one decade. On the part of science, this project will require constant scientific support, careful study of problematic issues, including issues of separate detention of categories of convicts that differ in their socio-demographic and criminological characteristics. This work can be carried out with the involvement of a wide range of domestic scientists and practitioners in the field of penal enforcement and related fields of activity.

\section{REFERENCES}

1. Akimzhanov T.K. Specialization as one of the necessary conditions for improving the effectiveness of the execution of criminal punishment in the form of imprisonment. In: Seliverstov V.I. (Ed.). Otbyvanie lisheniya svobody osuzhdennymi za ekonomicheskie i (ili) dolzhnostnye prestupleniya: itogi teoreticheskogo issledovaniya [Serving of imprisonment by persons convicted of economic and (or) official crimes: the results of a theoretical study]. Moscow: Yurisprudentsiya, 2019. $464 \mathrm{p}$

2. Aleksandrova I.A. From preferences to equality: waiting for changes in the new criminal economic policy. Vestnik Nizhegorodskoi pravovoi akademii=Herald of the Nizhny Novgorod Academy of Law, 2014, no. 3 (3), pp. 29-32. (In Russ.). 3. Bavsun M.V., Borkov V.N., Nikolaev K.D. The concept of modernization of criminal legislation in the economic sphere: a critical analysis. Nauchnyi vestnik Omskoi Akademii MVD Rossii=Scientific Bulletin of Omsk Academy of the Ministry of Internal Affairs of Russia, 2011, no. 4 (43), pp. 12-16. (In Russ.).

4. V Gosdume predlozhili kaznit' korruptsionerov i sdelat' dlya nikh otdel'noe kladbishche [The State Duma proposed to execute corrupt officials and bury them in a separate cemetery]. Available at: https://pikabu.ru/story/v_gosdume predlozhili_kaznit_korruptsionerov_i_sdelat_dlya_nikh_otdelnoe_kladbishche_6469852 (accessed August 1, 2021).

5. V Rossii mogut poyavit'sya chastnye tyur'my dlya biznesmenov [Private prisons for businessmen may appear in Russia]. Available at: http://www.dg-yug.ru/rubriki/world/89867-v-rossii-mogut-poyavitsya-chastnyie-tyurmyi-dlya-biznesmenov. html (accessed April 4, 2017).

6. Ivanov S. Separate sections for entrepreneurs accused of economic crimes will appear in pre-trial detention centers. Rusbase, September 12, 2018. Available at: https://rb.ru/news/sizo-business/ (accessed November 16, 2018). (In Russ.). 7. Interv'yu zamestitelya direktory FSIN Rossii na radiostantsii "Ekho Moskvy" 14 noyabrya 2018 goda. FSIN zayavila o nekhvatke mest $v$ koloniyakh dlya byvshikh silovikov [Interview of the Deputy Director of the Federal Penitentiary Service of Russia on the radio "Echo of Moscow" on November 14, 2018. FSIN announced a shortage of places in the colonies for former security forces officers]. Available at: https://iz.ru/812148/2018-11-14/fsin-zaiavila-o-nekhvatke-mest-vkoloniiakh-dlia-byvshikh-silovikov (accessed July 31,2021). 
8. Kleimenov M.P. Problems of codification of the criminal law: history, modernity, future (dedicated to the 200th anniversary of the draft Criminal Code of 1813). In: Komissarov V.S. (Ed.). Materialy VIII Rossiiskogo kongressa ugolovnogo prava, sostoyavshegosya 30-31 maya $2013 \mathrm{~g}$. [Proceedings of the 8th Russian Congress on Criminal Law, held on May 30-31, 2013]. Moscow: Yurlitinform, 2013. 684 p. (In Russ.).

9. Koroleva E. Do your time without trouble: scammers will be saved from rapists. Gazeta $R U$, September 12, 2018. Available at: https://www.gazeta.ru/social/2018/09/11/11960965.shtml (accessed November 16, 2018). (In Russ.).

10. Meško G. Expert opinion. In: Seliverstov V.I. (Ed.). Otbyvanie lisheniya svobody osuzhdennymi za ekonomicheskie $i$ (ili) dolzhnostnye prestupleniya: itogi teoreticheskogo issledovaniya [Serving of imprisonment by persons convicted of economic and (or) official crimes: the results of a theoretical study]. Moscow: Yurisprudentsiya, 2019. 464 p. (In Russ.).

11. Nikitina I.A. Improvement of the criminal legislation of the Russian Federation on responsibility for crimes in the sphere of economic activity. In: Komissarov V.S. (Ed.). Materialy VIII Rossiiskogo kongressa ugolovnogo prava, sostoyavshegosya 30-31 maya $2013 \mathrm{~g}$. [Proceedings of the 8th Russian Congress on Criminal Law, held on May 30-31, 2013]. Moscow: Yurlitinform, 2013. 684 p. (In Russ.).

12. Is there a need for private prisons in Russia? Special conditions of imprisonment are offered for businessmen. Kommersant FM, March 9, 2017. Available at: http://www.deloros.ru/nuzhny-li-chastnye-tyurmy-v-rossii.html (accessed April 5, 2017). (In Russ.).

13. On the Concept for development of the penal system of the Russian Federation for the period up to 2030: Resolution of the Government of the Russian Federation no. 1138-r of April 29, 2021. Sobranie zakonodatel'stva Rossiiskoi Federatsii [Collection of Legislation of the Russian Federation]. 2021. No. 20. Article 3397. (In Russ.).

14. Pertli L.F. Analytical review with proposals based on the results of the study of foreign experience of serving imprisonment by persons convicted of economic and official crimes, taking into account their criminological and socio-demographic characteristics. In: Seliverstov V.I. (Ed.). Otbyvanie lisheniya svobody osuzhdennymi za ekonomicheskie i (ili) dolzhnostnye prestupleniya: itogi teoreticheskogo issledovaniya [Serving of imprisonment by persons convicted of economic and (or) official crimes: the results of a theoretical study]. Moscow: Yurisprudentsiya, 2019. 464 p.

15. Rogozin spoke in favor of execution rather than imprisonment for corruption in the defense industry. Tekhnologii $i$ media=Technologies and the Media, August 8, 2021. Available at: https://www.rbc.ru/technology_and_media/08/08/2 021/610f07c09a7947abc280d855?utm_source=yxnews\&utm_medium=desktoptps (accessed April 5, 2017). (In Russ.).

16. Skakov A.B. Expert opinion. In: Seliverstov V.I. (Ed.). Otbyvanie lisheniya svobody osuzhdennymi za ekonomicheskie i (ili) dolzhnostnye prestupleniya: itogi teoreticheskogo issledovaniya [Serving of imprisonment by persons convicted of economic and (or) official crimes: the results of a theoretical study]. Moscow: Yurisprudentsiya, 2019. 464 p.

17. Smirnov L.B. Kriminologicheskie problemy ugolovnogo nakazaniya $v$ vide lisheniya svobody: korrektsiya tselepolaganiya, printsipov i realizatsii [Criminological problems of criminal punishment in the form of imprisonment: correction of goal-setting, principles and implementation]. Available at: http://www.criminologyclub.ru/home/3-last-sessi ons/297-2017-03-19-12-26-26.html (accessed March 20, 2017).

18. Shabanov V.B. Expert opinion. In: Seliverstov V.I. (Ed.). Otbyvanie lisheniya svobody osuzhdennymi za ekonomicheskie i (ili) dolzhnostnye prestupleniya: itogi teoreticheskogo issledovaniya [Serving of imprisonment by persons convicted of economic and (or) official crimes: the results of a theoretical study]. Moscow: Yurisprudentsiya, 2019. 464 p.

\section{INFORMATION ABOUT THE AUTHOR}

VYACHESLAV I. SELIVERSTOV - Doctor of Sciences (Law), Professor, Honored Scientist of the Russian Federation, professor of the Department of Criminal Law and Criminology at Lomonosov Moscow State University, Moscow, Russian Federation, professor of the Department of Criminal-Legal Disciplines at Moscow State Linguistic University, Moscow, Russian Federation. ORCID: https://orcid.org/0000-0002-9554-5438, e-mail: vis_home@list.ru

Received August 5, 2021 